\title{
PROBLEMATIKA DAN TANTANGAN SANTRI DI ERA REVOLUSI INDUSTRI 4.0
}

\author{
DEWI LISNAWATI
}

\begin{abstract}
Pesantren is one of the oldest educational institutions in Indonesia that has better capabilities than other educational institutions in terms of character building. Based on the results of previous studies explained that the students have some strong positive characters and weak positive characters. Five strong positive characters in the students themselves are gratitude, fairness, citizenship, kindness and hope. While weak positive characters include self regulation, bravery, creativity, perspective, and humor. Some of these weak positive characters if related to the four 21st century skills competencies, these weak positive characters can be challenges and obstacles of students in the industrial revolution era 4.0. To answer these challenges the pesantren especially the traditional pesantren must start responding actively through curriculum renewal and learning methods, but without eliminating the culture, values and characteristics of the traditional pesantren.
\end{abstract}

Keywords: Pesantren, Santri, Industrial Revolution 4.0

\section{Pendahuluan}

Pendidikan merupakan serangkaian suatu system yang berfungsi untuk memanusiakan manusia melalui proses pembelajaran pengetahuan dan keterampilan yang ditransferkan dari satu generasi ke generasi berikutnya. Sejatinya pendidikan dibentuk untuk mencerdaskan manusia melalui serangkaian pembelajaran dan transfer ilmu.

Hal tersebut sejalan dengan Undang-Undang Sistem Pendidikan Nasional Nomor 20 Tahun 2003 Pasal 3 tentang tujuan pendidikan. Melalui system pendidikan, diharapkan dapat membentuk kualitas manusia yang beriman, bertaqwa kepada tuhan Yang Maha Esa, berkepribadian kuat, berakhlak dan berbudi pekerti luhur, cerdas terampil, serta dapat menjalin hubungan baik antar sesama manusia di tengah-tengah lingkungannya.

Pendidikan dapat ditempuh melalui bimbingan orang tua dan otodidak. Penyelenggaraan pendidikan dilaksanakan melalui tiga jalur pendidikan yaitu jalur formal, nonformal dan informal. Menurut Undang-undang Sistem Pendidikan Nasional Nomor 20 Tahun 2003 Pasal 13 ayat 1 menyebutkan bahwa jalur pendidikan terdiri atas pendidikan formal, pendidikan nonformal dan pendidikan informal. 
Pendidikan jalur formal adalah pendidikan yang didapat dari sekolahsekolah resmi yang berada pada naungan pemerintah atau swasta. Seperti SD/MI, SMP/MTs, SMA/SMK dan Perguruan Tinggi. Jalur pendidikan nonformal merupakan pelaksanaan pendidikan diluar pendidikan formal yang dapat dilaksanakan secara terstruktur dan berjenjang. Biasanya didapat melalui Paket A, Paket B, Paket C, PKBM, majlis taklim, lembaga kursus, sanggar dan lain-lain. Sedangkan pendidikan informal adalah pendidikan dalam keluarga dan lingkungan sekitar yang berbentuk kegiatan kegiatan belajar. Seperti pendidikan agama, pendidikan budi pekerti, etika, sopan santun.

Pesantren merupakan sebuah lembaga pendidikan dan penyiaran agama Islam (Dawam Rahardjo dalam Rifa'I, 2017:22). Pesantren sejak awal didirikan memang bukan diperuntukan membentuk tenaga kerja terampil pada sektor-sektor bisnis atau perusahaan seperti lembaga-lembaga pendidikan formal lain pada umumnya. Tetapi pesantren lebih kepada bagaimana para santri dapat memahami, menghayati, dan mengamalkan ajaran agama Islam secara baik serta kaderisasi ulama (Azra dalam Syafe'i, 2018:93).

Saat ini para pemegang kepentingan di pondok pesantren tentu merasa bangga dan bersyukur karena meningkatnya perhatian masyarakat dan pemerintah pada dunia pendidikan dan lembaga pesantren. Dari semula pesantren merupakan sebuah lembaga yang tidak diakui keberadaannya hingga sekarang dengan di sahkannya Undang-undang Nomor 18 Tahun 2019 tentang pesantren dimana inti dari undang-undang tersebut mengatur tentang penyelenggaraan fungsi pendidikan, fungsi dakwah, dan fungsi pemberdayaan masyarakat.

Dengan di resmikannya undang-undang tersebut maka pesantren sebetulnya diharapkan dapta berperan menciptakan dukungan sosial bagi pembangunan Indonesia. Sebuah dukungan aktif dan dinamis dari para santrinya untuk ikut serta dalam pembangunan nasional yang sedang berlangsung saat ini.

Ketika pesantren sudah diakui secara legal oleh pemerintah, disisi lain kita sebaiknya tidak cepat bangga dan optimis dengan kondisi saat ini sebab semakin berat tanggungjawab yang dihadapi oleh para pengelola pesantren untuk mencetak kualitas santri yang mampu untuk berkontribusi dalam pembangunan nasional di Indonesia. Padahal kalau lihat keyataannya, pesantren-pesantren kita masih memiliki banyak kekurangan tentunya lebih baik kita introspeksi diri dengan mengidentifikasi semua kekurangankekurangan pesantren dan mencari solusi penyelesaiannya.

Seiring dengan berkembangnya zaman maka persoalan-persoalan yang harus dihadapi dan direspon oleh pesantren juga semakin kompleks dan harus mulai kita sadari dari sekarang. Persoalan yang dimaksud adalah persoalan modernisasi atau kehidupan modern. Semua implikasi dari 
modernisasi itu sebetulnya positif yaitu berupa kemajuan ilmu dan teknologi. Tetapi dengan adanya kemajuan ilmu dan teknologi semakin banyak sisi negatif yang ditimbulkan misalnya memudarnya nilai-nilai budaya ketimuran kita, nilai-nilai religius di kalangan anak muda dan adanya degradasi moral.

Apabila pesantren diharapkan memberikan respon atas persoalan diatas maka secara tidak langsung pesantren dihadapkan pada dua aspek yaitu yang nasional meliputi pembangunan nasional dan yang sifatnya universal yaitu perkembangan ilmu dan teknologi atau yang lebih kita kenal dengan revolusi industri 4.0. (Madjid, 1997:74)

Seiring dengan berkembangnya teknologi atau yang lebih dikenal sebagai Revolusi Industri 4.0. seharusnya pesantren ikut bertransformasi dalam meningkatkan kualitas layanan pendidikan sehingga peran pesantren tidak lagi hanya sebagai sarana untuk transfer ilmu agama, kaderisasi ulama tetapi lebih dari itu pesantren saat ini harus mampu membentuk karakter dan life skill para santri.

Dengan system pendidikan dan kurikulum yang khas, pesantren mencetak santri dengan berbagai karakteristik psikologis yang sama sebagaimana halnya non-santri, bahkan dalam beberapa hal lebih baik daripada non-santri (Fuad Nashori, 2011:204). Menurut penelitian, santri memiliki karakteristik psikologis positif tetapi ada yang menonjol dan ada juga yang lemah. Karakteristik psikologis yang cenderung menonjol seperti sikap yang positif terhadap perilaku pro-lingkungan hidup, kepuasan hidupnya sedang, kebermaknaan hidup, sabar dan kontrol dirinya sedang. Karakteristik psikologis yang cenderung lemah seperti regulasi diri, keberanian, kreativitas, keragaman sudut pandang dan humor. (Fuad Nashori, 2011:217). Dengan keragaman karakter yang dimiliki oleh para santri dalam hal ini karakteristik lemah tentu saja bagi para santri akan menjadi problematika dalam menghadapi berbagai tantangan dan problematika di era Revolusi Industri 4.0.

Berangkat dari permasalahan diatas, jurnal ini akan membahas mengenai problematika dan tantangan kaum santri di era revolusi industri 4.0 ditinjau dari segi karakteristik positif lemah yang dimiliki para santri dan karakteristik kompetensi seperti apa yang dibutuhkan oleh para santri di era disrupsi seperti sekarang ini. Kemudian strategi seperti apa yang dapat dilakukan oleh pesantren untuk mempersiapkan para santri dalam rangka menghadapi perkembangan teknologi supaya sehingga para santri dapat survive.

\section{Metode Kajian}

Artikel hasil kajian ditulis dengan menggunakan metode critical review (tinjauan kritis), tetapi digabungkan dengan refleksi penulis terhadap isu-isu pendidikan pondok pesantren di tengah revolusi industri 4.0. Melalui penggabungan dua metode tersebut diharapkan dapat diperoleh informasi 
hasil kajian kritis tentang eksistensi dan dinamika pondok pesantren di tengah revolusi industri 4.0.

\section{Hasil Kajian dan Pembahasan}

Menurut asal katanya pesantren berasal dari kata santri yang mendapat imbuhan awalan pe dan akhiran an yang menunjukkan tempat. Dengan demikian pesantren dapat diartikan sebagai tempat santri. (Nizar, 2007:286) dalam pendapat lain bahwa pesantren berasal dari kata "santri" yang menurut kamus umum bahasa Indonesia kata ini mempunyai dua pengertian, yaitu (1) orang yang beribadah dengan sungguh-sungguh, orang saleh. (2) Orang yang mempelajari dalam pengkajian agama Islam dengan berguru ketempat yang jauh seperti pesantren. (Gelba, 1995:1)

Prof. Johns berpendapat bahwa istilah santri berasal dari bahasa Tamil, yang berarti guru mengaji, sedang C.C. Berg mengatakan berasal dari bahasa India yang berarti orang yang tahu buku-buku suci agama Hindu atau seorang sarjana yang mengerti kitab suci agama Hindu. Kata shastri berasal dari shastra yang berarti buku suci, buku agama atau buku-buku tentang ilmu pengetahuan. (Dhofir dalam Musthofa, 2015:7). Dari pengertian tersebut kita dapat mengambil kesimpulan bahwa pesantren merupakan suatu tempat atau lembaga untuk orang-orang dalam mencari, mempelajari dan mengkaji agama Islam.

Secara histroris, pondok pesantren merupakan lembaga pendidikan tertua yang ada di Indonesia. Terdapat dua pendapat mengenai asal usul berdirinya pondok pesantren di Indonesia. Pendapat pertama menyebutkan bahwa pondok pesantren berakar pada tradisi Islam sendiri dan pendapat kedua mengatakan bahwa sistem pendidikan model pondok pesantren adalah asli Indonesia (Wiranata, 2018:69).

Pondok pesantren mulai berdiri sejak penyebaran Islam di Nusantara pada abad ke 15. Tokoh yang pertama mendirikan adalah Syekh Maulana Malik Ibrahim yang berasal dari Gujarat India, sekaligus tokoh pertama yang mengIslamkan Jawa. Maulana malik Ibrahim dalam mengembangkan dakwahnya menggunakan masjid dan pesantren, sebagai pusat transmisi keilmuan Islam. Pada gilirannya, transmisi yang dikembangkan oleh Maulana Malik Ibrahim melahirkan Wali Songo dalam jaringan ulama. Dari sinilah Raden Rahmad (Sunan Ampel) mendirikan pesantren pertama di Kembangkuning Surabaya tahun 1619 (Musthofa, 2015:7).

Pesantren di Indonesia dapat dibedakan menjadi dua kelompok yaitu pesantren tradisional (salaf) dan pesantren modern (Shofiyyah dkk, 2019:3). Keduanya mempunyai tujuan yang sama yaitu mencerdaskan kehidupan bangsa. Menurut data statistik dari pendis kementerian agama republik Indonesia tahun 2019 jumlah pesantren di Indonesia menunjukkan bahwa pesantren salaf menempati posisi jumlah tertinggi di angka $49.4 \%$. 


\section{Statistik Pendidikan Diniyah dan Pesantren}

Tipologi Pondok Pesantren

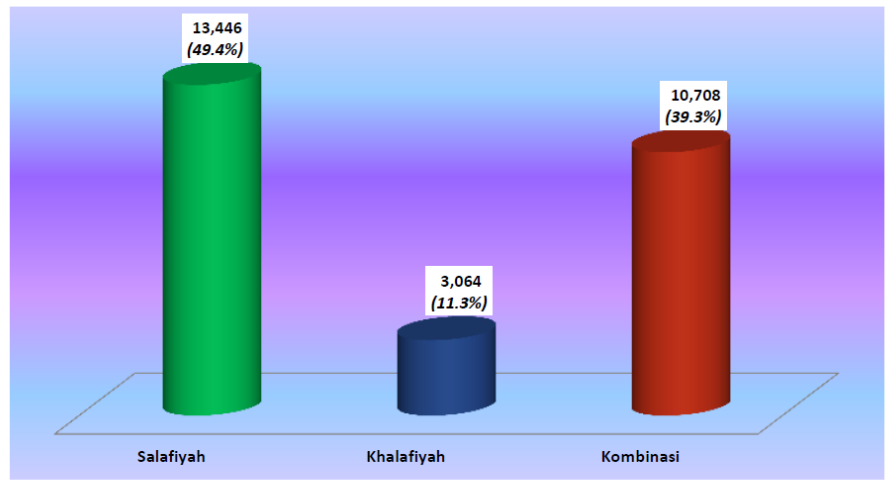

Jumlah Pondok Pesantren : 27.218

Gambar 1. Data Statistik Jumlah Pondok Pesantren di Indonesia Tahun 2019

Pesantren salaf atau tradisional bisaanya hanya mempelajari ilmu-ilmu terdahulu yang ada dalam kitab-kitab klasik karangan ulama terdahulu dan sama sekali tidak ada mata pelajaran umum. Kitab-kitab yang dipelajari di pesantren salaf bisaanya meliputi tafsir, hadits, fiqih, tasawuf, ilmu akhlak, nahwu, sharaf, tafsir dan lain-lain. Metode belajar yang dipergunakan di pesantren salaf mencakup sorogan, majelis ta'lim dan wetonan. (Hasbullah, 1996:50-52).

Pesantren khalafiyah atau modern pertama kali diperkenalkan oleh pondok pesantren Gontor. Dimana kurikulum di pesantren modern tidak sama seperti pesantren tradisional. Kurikulum pesantren modern memadukan antara kurikulum pesantren salaf dengan kurikulum pendidikan Islam sedangkan kurikulum pesantren dialokasikan dalam muatan lokal atau mungkin diterapkan melalui kebijakan sendiri. Metode belajar yang dipergunakan pada pondok pesantren modern bukan motode yang dipergunakan seperti di pesantren salaf, metode yang digunakan meliputi diskusi, seminar, tanyajawab dan metode problem solving.

Pada dasarnya pesantren terdiri dari beberapa unsur yaitu kyai, santri, mesjid, asrama, dan kitab klasik. Kelangsungan pondok sangat tergantung kepada seorang guru atau kyainya yang menjadi pemimpin atau meneruskannya. Jika pemimpin menguasai ilmu agama dengan sepenuhnya dan juga mempunyai kewibawaan, keterampilan dalam mengajar dan hal lainnya diperlukan maka hal diatas sangat menunjang terhadap berkembangan dan keberlangsungan suatu pondok pesantren.

Kyai merupakan elemen penting pada sebuah pesantren. Kyai sebagai pemimpin diharapkan mampu mengarahkan, dan memberi tauladan yang baik bagi santri-santrinya sehingga para santri bisa mengamalkan dan mengaplikasikan semua ajaran yang diperoleh. Dalam konteks keberlangsungan suatu pesantren, kyai dapat dilihat dari empat perspektif 
yakni kemampuan kepemimpinan ilmiah, kemampuan spiritual, kemampuan sosial, dan kemampuan administrasi. Jadi beberapa kemampuan tersebut mestinya terpadu pada pribadi kyai dalam kapasitasnya sebagai pengasuh dan pembimbing santri (Qomar, 2015:20).

Unsur kedua dari pesantren adalah santri. Kata "santri" itu (sekurangkurangnya) ada dua pendapat yang bisa kita jadikan acuan. Pertama pendapat yang mengatakan bahwa "santri" itu berasal dari kata "sastri", sebuah kata dari bahasa Sanskerta, yang artinya melek huruf (Madjid, 1997:28). Dari sini penulis mengasumsikan bahwa santri adalah orang yang tahu ilmu agama dan tahu membaca Al-Qur'an.

Kedua, adalah pendapat yang mengatakan bahwa perkataan santri sesungguhnya berasal dari bahasa Jawa, persisnya dari kata cantrik, yang artinya seseorang yang selalu mengikuti seorang guru ke mana guru ini pergi menetap (Madjid, 1997:28). Artinya santri adalah seseorang yang tha'at kepada kyai-nya dengan tujuan untuk mendapatkan keberkahan ilmu.

Menurut data statistic dari Pendidikan Islam Kementerian Agama Republik Indonesia tahun 2019, terdapat sekitar 3.642 .738 orang yang mondok baik di pesantren salaf, pesantren khalaf (modern) maupun pesantren kombinasi.

\section{Statistik Pendidikan Diniyah dan Pesantren}

Santri Pondok Pesantren

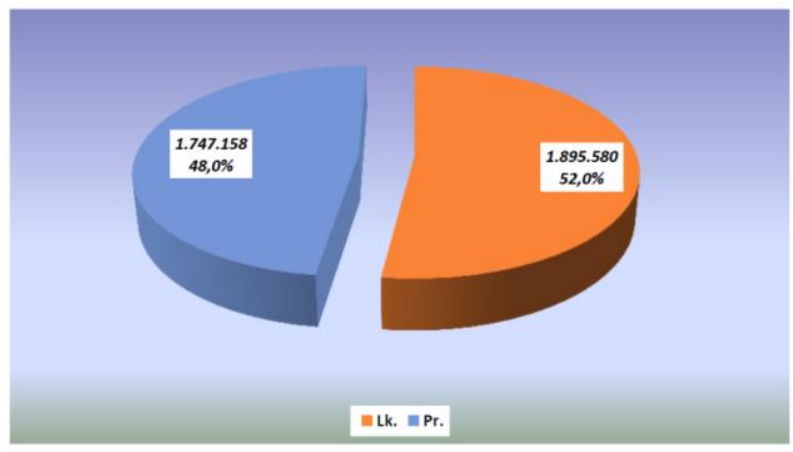

Jumlah Santri Pondok Pesantren : 3.642.738

Gambar 2. Data Statistik Jumlah Santri Pondok Pesantren di Indonesia Tahun 2019

Pesantren saat ini terutama pesantren salaf (tradisional) dihadapkan pada tantangan pembangunan nasional dan kemajuan teknologi sehingga mau tidak mau pesantren harus dapat mengembangkan kualitas layanan pendidikan agar mampu mencetak santri dengan skill yang dibutuhkan pada era disrupsi seperti sekarang ini. Pada umumnya pesantren salaf menjadikan kyai sebagai sumber dari segala referensi, mengutamakan pembelajaran penguasaan ilmu agama, tidak memiliki kurikulum yang terstruktur, jauh dari nilai-nilai pendidikan kritis, kreatif serta miskinnya kebijakan terhadap pengembangan mutu santri (Aziz, Safrudin dan Fajriyah, 2017:353) 
Peran pesantren seharusnya saat ini tidak hanya sebatas kepada transfer ilmu tetapi juga sebagai kaderisasi ulama, sebagai pemelihara budaya Islam, dan sebagai lembaga social serta penyiaran agama yang membentuk karakter kepribadian para santri. Tidak bisa dipungkiri bahwa output dari pesantren terutama pesantren salaf (tradisional) adalah santri dengan karakter khas. Kekhasan karakter itu tumbuh dari pola pendidikan dipesantren salaf yang cenderung satu arah.

\section{Karakter Santri}

Sebagaimana telah disinggung diawal bahwa seiring dengan berkembangnya zaman maka persoalan-persoalan yang harus dihadapi dan dijawab oleh lembaga pendidikan terutama pesantren semakin kompleks dan harus mulai kita sadari dari sekarang. Persoalan yang dimaksud adalah persoalan modernisasi atau kehidupan modern. Semua implikasi dari modernisasi itu sebetulnya positif yaitu berupa kemajuan ilmu dan teknologi. Tetapi dengan adanya kemajuan ilmu dan teknologi semakin banyak sisi negatif yang ditimbulkan misalnya memudarnya nilai-nilai budaya ketimuran kita, nilai-nilai religius di kalangan anak muda dan adanya degradasi moral.

Menurut banyak pendapat, kata "karakter" berasal dari kata dalam bahasa latin, yaitu "kharakter," "kharassein," dan "kharax," yang bermakna "tools for marketing," "to engrave," dan "pinted stake." Kata ini mulai digunakan dalam bahasa prancis sebagai "character" pada abad ke-14. Ketika masuk ke dalam bahasa Inggris, kata "character" ini berubah menjadi "charac-ter." Adapun di dalam bahasa Indonesia kata "character" ini mengalami perubahan menjadi "karakter" (Wibowo dalam Pratama, 2019:202). Secara bahasa karakter ialah tabiat; watak; sifat-sifat kejiwaan, akhlak, atau budi pekerti yang membedakan seseorang dengan yang lain. Secara istilah karakter adalah sifat utama yang terukir dan menyatu dalam pikiran, perasaan, keyakinan, dan perilaku seseorang yang membedakannya dengan orang lain (Maragustam dalam Pratama, 2019:203). Dari pengertian tersebut karakter dapat diartikan sebagai watak, tabi'at, kepribadian atau nilai-nilai yang diyakini oleh seseorang yang terbentuk oleh beberapa faktor seperti gen dan lingkungan.

Sejatinya pesantren merupakan satu-satunya lembaga pendidikan yang memiliki nilai lebih dalam membentuk dan mengembangkan karakter santri serta meminimalkan degradasi moral. Melalui berbagai ilmu dan kitab-kitab kemudian juga kultur yang terbentuk dalam lingkungan pesantren mendukung untuk pembentukan karakteristik santri yang khas.

Berdasarkan hasil penelitian terdahulu terdapat lima karakter positif menonjol dan lima karakter positif yang lemah. Lima karakter positif menonjol pada diri santri adalah kebersyukuran (gratitude), keadilan (fairness), kewargaan (citizenship), kebaikan hati (kindness) dan harapan (hope). Sedangkan karakter positif lemah meliputi regulasi diri (self regulation), 
keberanian (bravery), kreativitas (creativity), keragaman sudut pandang (perspective), dan humor (Anshori, 2011:211).

Dalam penelitian lain lebih lanjut mengatakan bahwa secara umum santri mempelajari banyak ragam pengetahuan yang berhubungan dengan nilai-nilai agama yang bersifat positif bagi kehidupannya, baik dalam hubungannya dengan sang pencipta, sesama manusia dan alam sekitar. Selama di pondok pesantren para santri cenderung mengadopsi nilai-nilai Islam seperti persaudaraan, persatuan, tolong menolong dan ketaatan kepada Allah SWT, Rasul, Ulama/Kyai dan orang-orang yang dianggap sebagai pemimpin. Persaudaraan, persatuan dan tolong menolong adalah nilai-nilai yang membentuk karakter kebersyukuran (gratitude), kebaikan hati (kindness) dan kewargaan (citizenship). (Rahardjo dalam Anshori, 2011:211212)

Kebersyukuran (gratitude). Kebersukuran merupakan elemen penting yang diterapkan di pondok pesantren. Mereka cenderung untuk menerima apa yang ada, sadar dan bersyukur atas apa yang tuhan berikan. Nilai-nilai kebersukuran ini juga tercantum dalam Al-Qur'an Surat Al-Baqoroh: 152 yang berbunyi:

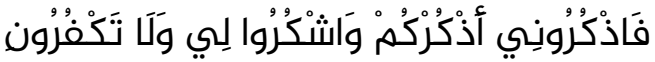

Artinya: Maka ingatlah kamu kepada-Ku, niscaya Aku ingat pula kepadamu dan bersyukurlah kepada-Ku dan janganlah kamu mengingkari nikmat-Ku. (Q.S. Al-Baqoroh: 152)

Pada ayat lain Al-Qur'an Surat An-Nahl ayat 114 yang berbunyi:

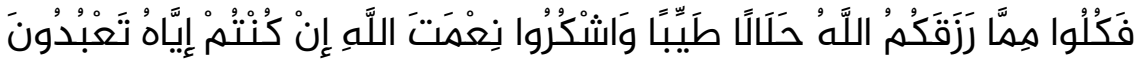

Artinya: Maka makanlah yang halal lagi baik dari rezeki yang telah Allah berikan kepadamu dan bersyukurlah kamu atas nikmat Allah, jika memang hanya kepada-Nya kamu menyembah. (Q.S. An-Nahl: 114)

Keadilan (fairness). Indikator keadilan yang dimiliki oleh santri adalah memperlakukan setiap orang secara adil, memberikan kesempatan yang sama pada setiap orang dan tidak membiarkan perasaan subjektif mempengaruhi keputusan yang menyangkut orang lain (Anshori, 2011:213). Keadilan sendiri merupakan salah satu nilai yang diterapkan dipondok dengan penekanannya pengamalan ayat al-qur'an tentang pentingnya bersikap adil, salah satunya yaitu Al-qur'an Surat Al-A'raf ayat 29-30: 


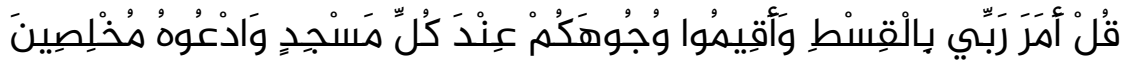

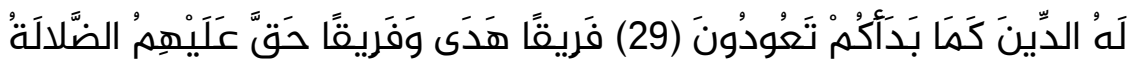

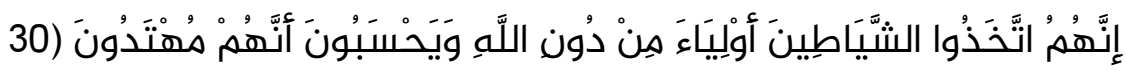
Artinya: Katakanlah, "tuhanku menyuruhku berlaku adil. Dan hadapkamlah wajahmu (kepada Allah) pada setiap sholat dan sembahlah dia dengan mengikhlaskan ibadah semata-mata hanya kepada-Nya. Kamu akan dikembalikan kepada-Nya sebagaimana kamu diciptakan semula. (Q.S. Al-A'raf: 29)

Sebagian diberi-Nya petunjuk dan sebagian lagi telah pasti kesesatan bagi mereka. Mereka menjadikan setan-setan sebagai pelindung selain Allah dan mereka mengira bahwa mereka mendapat petunjuk. (Q.S. Al-A'raf: 30)

Kewargaan (citizenship) dan kebaikan hati (kindness). Indikator dari kewarganegaraan adalah bekerja dengan baik pada situasi kelompok dan setia kepada kelompok (Anshori, 2011:213). Dengan kata lain santri memiliki kemampuan teamwork yang sangat baik, mereka cenderung solid dan setia kawan. Kekuatan karakter ini menurut penulis tumbuh karena pada kehidupan sehari-hari para santri mereka tinggal bersama para santri lain di sebuah asrama sehingga mudah bagi mereka untuk saling berbagi dan tolong menolong antar sesama para santri. Karakter kewargaan ini berbanding lurus dengan karakter kebaikan hati (kindness) dimana yang menjadi indikator kebaikan hati adalah melakukan kebaikan kepada orang lain, menolong orang lain, menjaga orang lain dan mengerti perasaan orang lain.

Pengamalan karakter kewargaan dan kebaikan hati ini tentu saja berdasarkan nila-nilai yang terdapat dalam ajaran Islam dan al-qur'an diantaranya sebagai berikut:

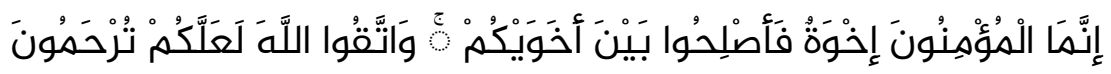

Artinya: Orang-orang beriman itu sesungguhnya bersaudara. Sebab itu damaikanlah (perbaikilah hubungan) antara kedua saudaramu itu dan takutlah terhadap Allah supaya kamu mendapat rahmat. (Q.S. Al-Hujurat: 10)

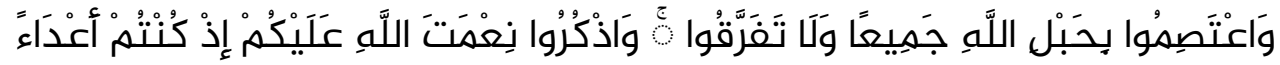

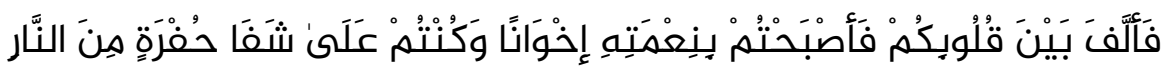

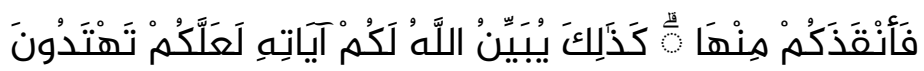


Artinya: Dan berpeganglah kamu semuanya kepada tali (agama) Allah, dan janganlah kamu bercerai berai, dan ingatlah akan nikmat Allah kepadamu ketika dahulu (masa jahiliyah) bermusuhmusuhan, maka Allah mempersatukan hatimu, lalu menjadilah kamu karena nikmat Allah orang-orang yang bersaudara. (Q.S. Ali Imran: 103)

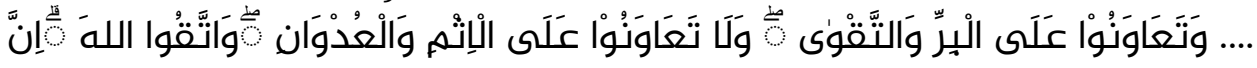

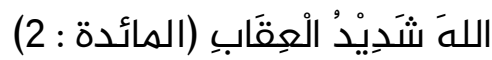

Artinya: ..... Dan tolong-menolonglah kamu dalam (mengerjakan) kebajikan dan taqwa, dan jangan tolong-menolong dalam berbuat dosa dan pelanggaran. Dan bertaqwalah kamu kepada Allah, sesungguhnya Allah amat berat siksa-Nya (Q.S. AlMaidah: 2)

Harapan (hope). Karakter positif dan menonjol pada diri santri yang terakhir adalah harapan dengan indikator adalah mengharapkan yang terbaik untuk masa depan dan berusaha untuk mewujudkannya, yakin dan percaya bahwa nasib bisa berubah dan masa depan yan baik bisa dicapai serta memiliki pandangan positif. (Anshori, 2011:214).

Harapan akan masa depan yang lebih baik tertanam dari pengamalan nilai-nilai ajaran Islam yang terkandung dalam ayat-ayat suci al-qur'an dimana salah satu ayat menerangkan bahwa setelah kesulitan itu aka nada kemudahan yakni surat Al-Insyirah ayat 6:

$$
\text { إنَّ هَعَ الْعُسْرْ يُسْرًا }
$$

Artinya: Sesungguhnya sesudah kesulitan itu ada kemudahan (Q.S. Al-Insyirah: 6)

Di samping karakter-karakter positif menonjol diatas, ada pula karakter-karakter positif lemah yang dimiliki oleh santri diantaranya yaitu: regulasi diri, keberanian diri, kreativitas, keragaman sudut pandang, dan humor. Para santri yang menjadi objek penelitian ini rata-rata berada pada usia 18 tahun atau saat usia mahasiswa, pada usia ini seseorang cenderung bebas dalam mengekspresikan diri sehingga kemungkinan tingkat kedisiplinan mereka rendah termasuk kemampuan untuk mengontrol emosi dan selera.

Faktor lain yang mendukung terhadap lemahnya karakter positif santri adalah karena para santri tinggal di lingkungan pondok pesantren yang notabene budaya lingkungannya kolektivistik terlebih bagi para santri yang mondok di pesantren-pesantren salaf (tradisional). Di pesantren salaf umumnya mereka masih mempertahankan dan menekankan budaya 
kepatuhan (tha'at), mereka cenderung takut terhadap ancaman, tantangan, kesulitan, tidak berani mengutarakan keinginan, tidak memiliki rasa humor, kurang kreativitas dan life skill karena di pesantren tradisional hanya mengkaji kitab-kitab klasik tanpa adanya keterpaduan dengan ilmu-ilmu pengetahuan umum lainnya serta mereka lebih memilih berperilaku selaras sesuai dengan aturan atau budaya yang berlaku dipesantren tersebut.

Dari hasil penelitian diatas dapat kita simpulkan bahwa seluruh nilainilai dan ilmu yang di kulturkan dan diajarkan di pesantren dapat membentuk karakter serta skill para santri. Kita tentu saja tidak dapat menghindar dari pembangunan nasional dan kemajuan teknologi, sehingga kita perlu melihat keterkaitan antara karakter-karakter positif lemah santri dengan karakterkarakter yang diperlukan di era revolusi industri 4.0 yang akan dibahas secara rinci pada point selanjutnya.

\section{Problematika dan Tantangan Santri Di Era Revolusi Industri 4.0}

Jika pada point sebelumnya sudah dibahas secara rinci mengenai karakter positif lemah pada diri santri maka pada point ini penulis mencoba menguraikan tentang sejarah revolusi industri dan karakteristik keterampilan seperti apa yang dibutuhkan pada era revolusi industri 4.0 berdasarkan dari beberapa literatur.

Transformasi digital dan pemanfaatan teknologi menjadi identitas revolusi industri 4.0. Teknologi informasi menjadi basis dalam kehidupan manusia. Semuanya tanpa batas dengan penggunaan daya dan data komputasi tak terbatas, karena dipengaruhi oleh perkembangan Internet dan teknologi digital masif sebagai tulang punggung gerakan manusia dan mesin serta konektivitasnya (Gazali, 2018:96).

Pada sejarah perkembangannya, revolusi industri pertama dimulai pada abad ke-18 atau yang lebih dikenal dengan sebutan revolusi industri 1.0 munculnya revolusi industri 1.0 ditandai dengan hadirnya mesin uap sebagai upaya untuk meningkatkan produktivitas yang bernilai tinggi. Kemudian revolusi industri 2.0 lahir pada tahun 1900-an yang ditandai dengan ditemukannya tenaga listrik. Selanjutnya revolusi industri berkembang lagi ke revolusi industri 3.0 ditandai dengan otomatisasi pada tahun 1970 atau tahun 1990-an hingga saat ini. Pada revolusi industri keempat atau 4.0 mulai terjadi efisiensi mesin dan manusia yang terkoneksi dengan internet.

Seiring dengan perkembangan teknologi dan tuntutan zaman, fungsi dan peran pendidikan saat ini bukan hanya sebagai transfer ilmu tetapi juga bagaimana lembaga pendidikan dapat membentuk output (lulusan) yang memiliki karakter dan keterampilan yang sesuai dengan kebutuhan di era revolusi 4.0 pesantren sebagai salah satu lembaga pendidikan pembentuk karakter yang saat ini keberadaan dan legalitasnya sudah diakui oleh pemerintah, tentu harus mulai memberikan respon tentang tantangan dan problematika yang mungkin akan dihadapi oleh para santrinya. Jika melihat 
dari segi karakter dan keterampilan, terdapat beberapa pendapat mengenai berbagai keterampilan dan kompetensi yang dibutuhkan pada era revolusi industri 4.0 seperti yang dikemukakan oleh UNESCO dan UNESCO Bangkok (2015) yaitu:

1. Berpikir Kritis dan Inovatif. Meliputi kreativitas, kewirausahaan, panjang akal, aplikasi pemikiran reflektif, dan pengambilan keputusan yang masuk akal.

2. Keterampilan Interpersonal. Meliputi keterampilan komunikasi, keterampilan berorganisasi, kerjasama tim (team work), kolaborasi, keramahan (sociability), empati dan kasih saying.

3. Keterampilan Intrapersonal. Meliputi disiplin diri, kemampuan untuk belajar mandiri, fleksibilitas dan kemampuan adaptasi, kesadaran diri, ketekunan, motivasi diri, kasih saying, integritas, mengambil resiko, harga diri.

4. Kewarganegaraan Global. Meliputi kesadaran, toleransi, keterbukaan, tanggungjawab, menghirmati keberagaman, pemahaman akan etika, pemahaman lintas budaya, partisipasi demokratis, penghormatan pada lingkungan, identitas nasional dan rasa memiliki.

5. Literasi media dan informasi. Kemampuan untuk mencari dan mengakses informasi melalui media ICT, perpustakaan dan arsip, mengekspresikan dan mengkomunikasikan ide melalui ICT, menggunakan media dan ICT untuk berpartisipasi dalam proses demokrasi, serta kemampuan untuk menganalisis dan evaluasi isi media.

Adapun US-based partnership for 21st Century Skills (P21), mengidentifikasi keterampilan berpikir kritis (Critical Thinking Skills), keterampilan berpikir kreatif (Creative Thinking Skills), keterampilan komunikasi (Communication Skills), dan keterampilan kolaborasi (Collaboration Skills) sebagai kompetensi yang diperlukan di abad 21 (Zubaidah, 2018:2).

1. Critical Thinking Skills. Merupakan salah keterampilan paling mendasar yang harus dimiliki pada era revolusi industri 4.0. keterampilan berpikir kritis meliputi kemampuan untuk mengidentifikasi dan menganalisis akar permasalahan kemudian mencari alternatif solusi permasalahan dengan tepat.

2. Creative Thinking Skills. Merupakan keterampilan yang berhubungan dengan keterampilan menggunakan pendekatan yang baru untuk menyelesaikan suatu permasalahan, inovasi dan penemuan. Keterampilan ini merupakan suatu tindakan yang benar-benar baru dan asli, baik secara probadi atau secara budaya (abdullah dan osman dalam Zubaidah, 2018:2). Contoh nyata dari berfikir kreatif seperti berpikir mengenai suatu masalah kemudian mendiskusikan gagasan pemikirannya dengan orang lain. 
3. Communication Skills. Merupakan kemampuan atau keterampilan dalam mengemukakan gagasan atau pendapat kepada orang lain baik dalam bentuk lisan maupun tulisan.

4. Collaboration Skills. Merupakan kemampuan bekerja sama, saling menghormati dan menghargai ketika bekerja dalam tim.

Jika kita membuat perbandingan antara karakter positif lemah santri dengan keterampilan abad 21 diatas, dapat diuraikan pada tabel berikut:

\begin{tabular}{|l|ll|}
\hline \multicolumn{2}{|c|}{ Keterampilan Abad 21 } & \multicolumn{1}{c|}{ Karakter Positif Lemah Santri } \\
\hline 1) Critical Thinking Skills & 1) Regulasi Diri (Self Regulation) \\
2) Creative Thinking Skills. & 2) Keberanian (Bravery) \\
3) Communication Skills & 3) Kreativitas (Creativity) \\
4) Collaboration Skills & 4) Keragaman Sudut Pandang (Perspective) \\
& 5) Humor \\
\hline
\end{tabular}

Tabel Perbandingan Karakter Positif Lemah Santri Dengan Keterampilan Abad 21

Dengan membandingkan antara keterampilan abad 21 dan karakter positif lemah santri maka dapat ditarik kesimpulan bahwa terdapat beberapa karakter yang masih harus ditingkatkan dan penulis kira hal tersebut merupakan bagian dari tantangan dan problematika yang akan para santri hadapi di era revolusi industri 4.0 diantaranya yaitu Keberanian (Bravery), Kreativitas (Creativity) dan Keragaman Sudut Pandang (Perspective). Keterkaitan antara karakter positif lemah santri dengan keterampilan abad 21 dapat digambarkan sebagai berikut:

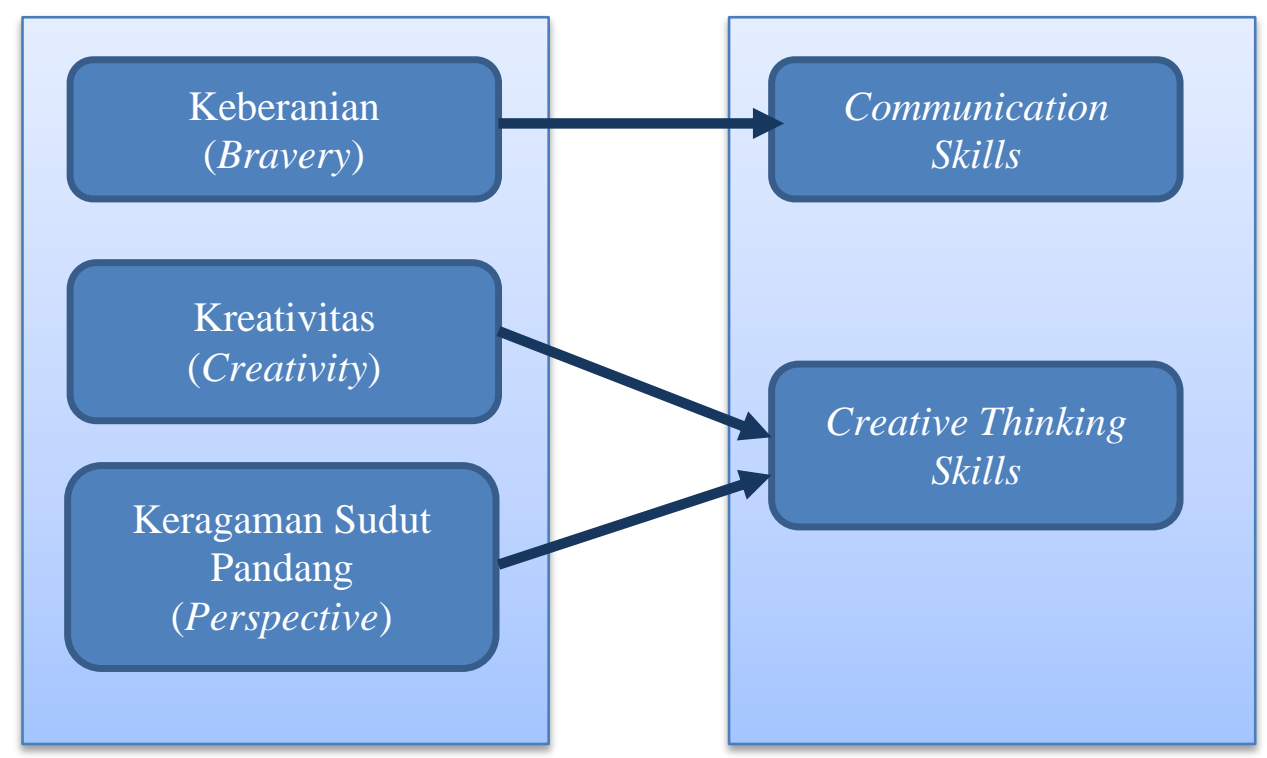

Gambar 3. Keterkaitan Antara Karakter Positif Lemah Santri dengan Keterampilan Abad 21 
Problematika ke-1: Keberanian (Bravery). Seperti yang telah dipaparkan sebelumnya bahwa tingkat keberanian para santri cukup lemah terutama pada indikator berani mengutarakan keinginan walaupun ada lawan. Jika dikaitkan dengan Communication Skills dimana kemampuan atau keterampilan dalam mengemukakan gagasan atau pendapat kepada orang lain baik dalam bentuk lisan maupun tulisan maka karakter keberanian (bravery) harus ditingkatkan.

Manusia merupakan makhluk sosial yang kesehariannya selalu berinteraksi dengan oran lain. Dalam proses interaksi tersebut tentu saja memerlukan suatu proses untuk menyampaikan ilmu, gagasan, pendapat yang dinamakan dengan komunikasi. Tujuan utama dari komunikasi adalah mengirimkan atau bertukar informasi dari satu orang ke orang lain sehingga kemampuan berkomunikasi sangatlah penting untuk mendukung kelancaran proses komunikasi. Terdapat beberapa tehnik dalam komunikasi, yaitu:

1. Ide pesan utuh, tidak memiliki makna ganda dan diucapkan dengan jelas, tegas dan tidak berbelit-belit.

2. Komunikator memahami betul lawan bicara.

3. Informasi disampaikan dengan bahasa penerima informasi dan disesuaikan dengan kemampuan serta tingkat kognisi penerima informasi.

4. Pembawa pesan harus mengendalikan noise dan mencari umpan balik untuk memastikan bahwa informasi yang disampaikan dapat dimengerti oleh penerima (Zubaidah, 2018:10)

Problematika ke-2: Kreativitas (Creativity) dan Keragaman Sudut Pandang (Perspective). Dalam hal kerativitas penulis mengaitkan dengan karakter Creative Thinking Skills. Kreativitas para santri harus ditingkatkan bukan hanya dari segi kemampuan berfikir secara kreatif, menganalisis permasalahan tetapi juga harus kaya akan sudut pandang. Hal ini menjadi penting ketika santri menghadapi persaingan dalam era revolusi industi 4.0.

Melatih keterampilan komunikasi membutuhkan waktu yang cukup banyak sehingga keterampilan komunikasi sebaiknya dilatih secara kontinue dan konsisten. Untuk meningkatkan keberanian santri terutama pada indikator keberanian mengutarakan keinginan maka harus dilatih communication skills para santri. Strategi untuk melatih communication skills dikalangan para santri terutama untuk santri yang belajar di pondok pesantren tradisional (salaf) diantaranya adalah dengan tidak lagi menerapkan metode pembelajaran halaqoh, sorogan dan bandongan tetapi juga harus ada pembaharuan metode pembelajaran ke arah klasikal. Misalnya dengan metode tanya jawab, diskusi dan seminar serta pemanfaatan teknologi selama proses pembelajaran.

Melalui metode pembelajaran halaqoh yang dikombinasikan dengan metode tanya jawab dan diskusi, maka para santri akan belajar untuk berdiskusi seputar isi suatu kitab. Sebaiknya pesantren tidak hanya 
menerapkan metode wetonan dan sorogan yang hanya mendengarkan dan menyimak apa yang disampaikan kyai tetapi juga sebaiknya santri dilibatkan selama proses pembelajaran melalui tanya jawab, diskusi aktif dan seminar. Dengan metode ini diharapkan keberanian dan keterampilan berkomunikasi para santri dapat ditingkatkan sehingga para santri dapat tetap survive di era revolusi industri 4.0 .

Kreativitas dianggap sebagai salah satu keterampilan yang harus dikuasai oleh setiap orang di era disrupsi. Kreativitas merupakan keterampilan penting bagi siswa karena memiliki hubungan langsung dengan pengembangan konten pengetahuan dan keterampilan (Livingston dalam Zubaidah, 2018:7).

Sebetulnya dalam sistem pembelajaran yang terjadi dalam pesantrenpesantren terutama pesantren salaf sangat kuat dengan sistem hafalan sehingga hal ini mendorong terjadinya verbalisme. Ketika para santri berdebat dengan teman sesamanya mereka akan lebih bersifat reproduktif artinya mengeluarkan kembali apa yang ada dalam otaknya yang disimpan melalui hafalan dan kurang kreatif dalam menciptakan pemikiran-pemikiran dan gagasan-gagasan baru yang merupakan hasil pengolahan sendiri.

Berdasarkan uraian diatas, menurut penulis strategi efektif dalam meningkatkan kreativitas dan perspektif para santri diantaranya melalui dibentuknya lajnah Bahtsul Masail yang dapat menjadi wadah bagi para santri yang mempunyai hobi diskusi dan beretorika. Seperti pada pesantren Lirboyo sebagai salah satu pesantren tradisional disana terdapat pula beberapa lajnah atau wadah kretivitas yang menampung aspirasi santri ( Muhakamurrohman, 2014:116).

Disamping itu, para kyai dalam mengajarkan ilmu-ilmu agama dan kitab-kitab kepada santri sebaiknya harus sudah mulai mencari metode mengajar yang dapat melatih keterampilan berpikir kreatif para santri seperti mengeksplorasi materi yang ada di kitab dengan implementasi pada kehidupan sehari-hari.

Selain strategi diatas menurut penulis untuk meningkatkan kualitas santri dalam rangka menghadapi era disrupsi, sebaiknya pihak pesantren harus menerapkan pembaharuan dan kebijakan tambahan untuk mendukung strategi diatas. Misalnya pengembangan life skills (kecakapan hidup) berbasis kearifan pesantren melalui pengembangan jiwa enterpreneurship santri.

Pesantren dapat membuka Balai Latihan Kerja (BLK) dengan pelatihan komputer, pelatihan bahasa, pelatihan menjahit, otomotif dan lain-lain sesuai minat bakat para santri. Upaya mengembangkan life skills dapat dilaksanakan secara spiritual dengan tanpa menghilangkan jiwa kesantrian.

\section{Kesimpulan}

Pesantren merupakan lembaga pendidikan tertua di Indonesia yang memiliki kemampuan lebih baik dalam membentuk karakter santrinya sesuai 
dengan kultur yang dipelihara pada pondok pesantren. Menurut hasil penelitian, karakter santri semua bersifat positif hanya saja ada yang menonjol dan ada juga yang lemah. Karakter santri yang menonjol meliputi kebersyukuran (gratitude), keadilan (fairness), kewargaan (citizenship), kebaikan hati (kindness) dan harapan (hope). Sedangkan karakter positif lemah meliputi regulasi diri (self regulation), keberanian (bravery), kreativitas (creativity), keragaman sudut pandang (perspective), dan humor.

Jika dikaitkan dengan empat kompetensi yang dibutuhkan pada era revolusi industri 4.0 yang terdiri dari mengidentifikasi keterampilan berpikir kritis (Critical Thinking Skills), keterampilan berpikir kreatif (Creative Thinking Skills), keterampilan komunikasi (Communication Skills), dan keterampilan kolaborasi (Collaboration Skills) maka karakter positif lemah yang dapat menjadi problematika dan tantangan para santri di era revolusi industri 4.0 adalah meliputi Keberanian (Bravery), Kreativitas (Creativity) dan Keragaman Sudut Pandang (Perspective).

Adapun strategi yang penulis ajukan untuk melatih karakter-karakter lemah para santri melalui pembaharuan metode belajar yang tentu saja pembaharuan ini harus disertai dengan pembaharuan pada kurikulum serta pengembangan jiwa enterpreneurship santri yang ada di pesantren terutama pada pesantren tradisional (salaf) tanpa merubah budaya dan nilai-nilai ciri khas pesantren salaf.

\section{DAFTAR PUSTAKA}

Aziz, Safrudin dan Fajriyah. (2017). Kebijakan Peningkatan Mutu Santri Melalui Pendidikan Berbasis Entrepreneurship. Vol 5(2): 351-368.

Gelba, Sindu. (1995). Pesantren Sebagai Wadah Komunikasi. Jakarta: PT. Rineka Cipta.

Gazali, Erfan. (2018). Pesantren Di Antara Generasi Alfa Dan Tantangan Dunia Pendidikan Era Revolusi Industri 4.0. Volume 2(2): 94-109.

Hasbullah. (1996). Kapita Selekta Pendidikan Islam. Jakarta: PT. Remaja Grafindo Persada.

Madjid, Nurcholish. (1997). Bilik-Bilik Pesantren. Paramadina: Dian Rakyat. Muhakamurrohman, Ahmad. (2014). Pesantren: Santri, Kiai dan Tradisi. Vol 12 (2):109-118).

Musthofa. (2015). Kedatangan Islam dan Pertumbuhan Pondok Pesantren Di Indonesia Perspektif Filsafat Sejarah. Vol 2 (1): 1-14.

Nashori, Fuad. (2011). Kekuatan Karakter Santri. Millah. Vol 11(1): 203-219.

Nizar, Samsul. (2007). Sejarah Pendidikan Islam: Menelusuri Jejak Sejarah Pendidikan Era Rasulullah Sampai Indonesia. Jakarta: Kencana.

Pratama, Dian Arif Noor. (2019). Tantangan Karakter Di Era Revolusi Industri 4.0 Dalam Membentuk Kepribadian Muslim. Vol 3(1): 198-226. 
Qomar, Mujamil. (2015). Pesantren dari Transfortasi Metodologi Menuju Demokrasi Institusi. Jakarta: Erlangga.

Rifa'I, Afga Sidiq. (2017). Pembaharuan Pendidikan Pesantren Dalam Menghadapi Tantangan dan Hambatan di Masa Modern. Vol 1(1): 2-38.

Shofiyyah, Nilna Azizatus, dkk. (2019). Model Pondok Pesantren Di Era Milenial. Vol 4(1): 1-18.

Syafe'i, Imam. (2017). Pondok Pesantren: Lembaga Pendidikan Pembentukan Karakter. Vol 8: 85-103.

Wiranata, RZ Ricky Satria. (2018). Tantangan, Prospek dan Peran Pesantren Dalam Pendidikan Karakter di Era Revolusi Industri 4.0. Jurnal Komunikasi dan Pendidikan Islam. Vol 8(1): 61-92.

Zubaidah, Siti. (2018). Mengenal 4C: Learning and Innovation Skills Untuk Menghadapi Era Revolusi Industri 4.0. Makalah Disampaikan Pada Seminar "2nd Science Education National Conference" di Universitas Trunojoyo, Oktober 13, Madura. 
